\title{
Adenoma Detection Rate in Colonoscopic Screening with Ketamine-based Sedation: A Prospective Observational Study
}

\section{Ketamin Bazlı Sedasyon ile Kolonoskopik Taramada Adenom Tespit Oranı: Prospektif Gözlemsel Bir Çalışma}

\author{
(D) Mirza KOVACEVIC1, (D) Nermina RIZVANOVIC1, (D) Adisa SABANOVIC ADILOVICI, D Nedim BARUCIJA², \\ (D) Anida ABAZOVIC 3
}

'Cantonal Hospital Zenica, Department of Anesthesiology and Intensive Care Unit, Zenica, Bosnia and Herzegovina ${ }^{2}$ Cantonal Hospital Zenica, Department of Otorhinolaryngology and Maxillofacial Surgery, Zenica, Bosnia and Herzegovina ${ }^{3}$ Cantonal Hospital Zenica, Department of Neurology, Zenica, Bosnia and Herzegovina

\begin{abstract}
Objective: This study aimed to determine the relationship between one of the most commonly used anesthesia techniques, ketaminebased sedation, on the value of adenoma detection rate (ADR) during colonoscopy screening.

Methods: This prospective, observational study included 140 patients, who underwent a standard colonoscopy preparation before the procedure. Sedation regimens included ketamine at $0.5 \mathrm{mg} / \mathrm{kg}$ and propofol at 0.5 $\mathrm{mg} / \mathrm{kg}$. Additional doses of propofol were administered at $0.5 \mathrm{mg} / \mathrm{kg}$ to maintain the Ramsey Sedation scale. Baseline characteristics, ADR, bowe preparation quality according to the Chicago bowel preparation (CHBP) scale, cecal intubation, colonoscopy removal, and complications were analyzed.

Results: The mean age of patients was 55.76 years; 40 (28.6\%) were males and $100(71.4 \%)$ were females. The ADR was $43.57 \%$, wherein $15.71 \%$ in males and $27.86 \%$ in females. There were $43.6 \%$ adenomas, $17.9 \%$ biopsies, and $22.9 \%$ polypectomies. The largest location of adenomas/polyps were in the rectum and sigmoid and ascending colon $(p=0.11)$, a biopsy of the sigmoid colon and ileum $(p<0.05)$, polypectomy of the rectum and sigmoid and ascending colon $(p<0.05)$. The cecal intubation was $93.6 \%$ with a withdrawal time that is $>6 \mathrm{~min}$ in most patients $(80 \%)(p<0.05)$. The CHBP scale showed good bowel preparation $(p<0.05)$ without complications.

Conclusions: Ketamine-based sedation is in good overall correlation with ADR. Therefore, the sedation technique should be included for ADR assessment in the future.

Keywords: Colonoscopy, sedation, adenoma
\end{abstract}

\section{öz}

Amaç: Bu çalışmada en sık kullanılan anestezi tekniklerinden biri olan ketamin bazlı sedasyon ile kolonoskopi taraması sırasında adenom tespit oranının (ADR) değeri arasındaki ilişkinin belirlenmesi amaçlanmıştır.

Yöntemler: Bu prospektif, gözlemsel çalışmaya, işlemden önce standart kolonoskopi hazırlığı yapılan 140 hasta dahil edildi. Sedasyon rejimleri, 0,5 mg/kg ketamin ve 0,5 mg/kg propofol içeriyordu. Ramsey Sedasyon skalasını korumak için $0,5 \mathrm{mg} / \mathrm{kg}^{\prime}$ de ek propofol dozları uygulandı. Temel özellikler, ADR, Chicago barsak hazırlık (CHBP) ölçeğine göre bağırsak hazırlığı kalitesi, çekal entübasyon, kolonoskopinin çıkarılması ve komplikasyonlar analiz edildi.

Bulgular: Hastaların ortalama yaşı 55,76 yıldı; 40' $(\% 28,6)$ erkek, 100'ü $(\% 71,4)$ kadındı. ADR, erkeklerde $\% 15,71$ ve kadınlarda $\% 27,86$ olmak üzere $\% 43,57$ idi. $\% 43,6$ adenom, $\% 17,9$ biyopsi ve $\% 22,9$ polipektomi vardı. Adenomların/poliplerin en büyük yeri rektumda ve sigmoid ve çıan kolonda $(p=0,11)$, sigmoid kolon ve ileum biyopsisinde $(p<0,05)$ rektum ve sigmoidde ve çıkan kolonda polipektomi $(p<0,05)$ idi. Çekal entübasyon, çoğu hastada $(\% 80)>6$ dakika olan bir geri çekme süresi ile \%93.6 idi $(p<0,05)$. CHBP ölçeği komplikasyonsuz iyi bir barsak hazırlığı $(p<0,05)$ gösterdi.

Sonuçlar: Ketamin bazlı sedasyon, ADR ile genel olarak iyi bir korelasyon içindedir. Bu nedenle, gelecekteki çalışmalarda ADR değerlendirmesi için sedasyon tekniği dahil edilmelidir.

Anahtar kelimeler: Kolonoskopi, sedasyon, adenom
Address for Correspondence: M. Kovacevic, Cantonal Hospital Zenica, Department of Anesthesiology and Intensive Care Unit, Zenica, Bosnia and Herzegovina

E-mail: kovacevic.mirza@hotmail.com ORCID ID: orcid.org/ORCID: 0000-0002-3492-4100
Received: 23 November 2021

Accepted: 11 January 2022

Online First: 20 January 2022

Cite as: Kovacevic M, Rizvanovic N, Sabanovic Adilovic A, Barucija N, Abazovic A. Adenoma Detection Rate in Colonoscopic Screening with Ketamine-based Sedation: A Prospective Observational Study. Medeni Med J 2022;37:79-84

${ }^{\circledR}$ Copyright 2022 by the Istanbul Medeniyet University / Medeniyet Medical Journal published by Galenos Publishing House.

Licenced by Creative Commons Attribution-NonCommercial 4.0 International (CC BY-NC 4.0) 


\section{INTRODUCTION}

Colorectal cancer is the third malignant disease in the global malignant tumor incidence, which is 3-4 times higher in males than in females in developed countries'. The 5-year survival of patients with colon cancer is $64 \%$, with $90 \%$ survival in those with localized cancer and $71 \%$ in regional cancer, with a decrease of up to $14 \%$ in those with distant cancer. As for rectal cancer, the 5-year cumulative prognosis is quite similar. Most of these cancers are diagnosed after the onset of symptoms or diagnostic colonoscopy ${ }^{2}$. Colonoscopy has become the gold standard screening test for colorectal cancer. The main goal of a diagnostic colonoscopy is cancer prevention, detection, adenoma, and polyp removal. As a diagnostic and therapeutic method, colonoscopy is widely used to detect colorectal cancer, and as such, significantly reduces mortality in these patients, which confirms the effectiveness of colonoscopy as a primary screening modality ${ }^{3}$. The primary indicator of the quality of colonoscopy is the adenoma detection rate (ADR). The ADR depends on several factors that are characterized by quality measures. They refer to the withdrawal time, rate of cecal intubation, and quality of bowel preparation. The proposed criterion for the ADR is a well-done endoscopic examination, which aimed to achieve the ADR benchmark of $25 \%{ }^{4}$. The recommended ADR of $15 \%$ or more for females and $25 \%$ or more for male patients is an indicator of adequate colonoscopy quality. The value of ADR may greatly vary, and the rate of adenoma detection has not yet been well confirmed in terms of its application in predicting the risk of developing colorectal cancer after colonoscopy 5 . Several factors are associated with ADR. Those that independently affect the occurrence of adenomas include age, gender, and personal history of adenomas. Others factors are directly associated with the ADR, such as the insertion time and the colonoscope retraction time ${ }^{6,7}$. The diagnostic accuracy and therapeutic safety of colonoscopic screening mainly depend on the quality of the bowel preparation; however, the impact of the form of anesthesia is insufficiently known on the ADR. Adequate sedation-based analgesia is necessary for the successful inspection of the colonic mucosa. Small data are related to the relationship of the influence of anesthesia technique on the ADR during colonoscopy screening. Therefore, this study aimed to evaluate the association between ADR and one of the most commonly used sedation techniques, ketamine-based sedation.

\section{MATERIALS and METHODS}

After obtaining the approval of the Cantonal Hospital Zenica Ethics Committee (decision no: 00-
03-35-1277-9/20, date: 30.06.2020) and informed consent from the patients, a prospective, observational study was conducted. The study included 140 patients older than 18 years, with the American Society of Anesthesiologists (ASA) status 1-2 and prescribed for elective colonoscopy. The study excluded patients who were pregnant, with previous abdominal surgery, malignant and respiratory diseases, gastrointestinal obstruction, using antihypertensive and antiarrhythmic drugs, psychiatric disorders, with other pain syndromes, ASA status of 3 and higher, and refused to participate in the research. The study included all patients who had previously undergone standard preparation procedure (MoviPrep) for the colonoscopy procedure. Upon entry into the endoscopic room, an intravenous line was set up and saline was intravenously started. Patients were placed in the left lateral position and monitored for noninvasive blood pressure, heart rate, and peripheral oxygen saturation with oxygen support via a face mask. Sedation was performed by one anesthesiologist, and the procedure was performed by two endoscopists.

\section{Sedation Regimen}

All patients were premedicated with midazolam at $0.05 \mathrm{mg} / \mathrm{kg} 5 \mathrm{~min}$ before the procedure. Ketamine at $0.5 \mathrm{mg} / \mathrm{kg}$ and propofol at $0.5 \mathrm{mg} / \mathrm{kg}$ was administrated and reached the Ramsey Sedation scale (RSS) at 5 . An additional dose of propofol was administrated at $0.5 \mathrm{mg} /$ $\mathrm{kg}$ for maintenance of RSS.

\section{Data Collection}

\section{Baseline Characteristics}

Upon patient identification, demographic data were collected including age, body weight, gender, ASA status (ASA 1 or 2), and type of colonoscopy (diagnostic or therapeutic).

\section{Assessment of the ADR}

ADR is defined as the rate at which a physician finds one or more precancerous adenomas/polyps during a normal colonoscopic screening procedure. It is calculated according to the formula: number of patients with at least one adenoma $\div$ total number of adequately performed colonoscopies $\times 100$. A polyp is defined as the outgrowth of mucosal tissue of the colon into its lumen, whereas an adenoma is defined as a polyp consisting of tissue that resembles the normal lining of the colon. During the colonoscopy, the total number and location of adenomas, biopsies, and polypectomies were recorded.

\section{Assessment of the Quality of Bowel Preparations}

The quality of intestinal preparation is numerically determined based on the Chicago Bowel Preparation 
(CHBP) scale (total colon), wherein 0 means a small amount of intestinal content $(\leq 50 \mathrm{cc})$; 1 means a minor amount of intestinal content (51-150 cc); 2 means mild amount of intestinal content (151-300 cc); and 3 means a large amount of intestinal content (>300 cc).

The total score ranges from a minimum of 0 (small) to a maximum of 3 (large). Scoring was performed before rinsing and removing the intestinal content.

\section{Assessment of Cecal Intubation and Withdrawal Time}

The cecal intubation is determined as the passage of the colonoscope to the site above the ileocecal valve, where the ileocecal valve and the appendix opening are shown. Cecal intubation is marked with YES or NO.

Colonoscope withdrawal time is determined as the total time spent in colon inspection. The standard withdrawal time is currently $6 \mathrm{~min}$ and is marked as $<6$ $\min$ and $>6$ min.

\section{Assessment of Complications}

Complications that were followed include bowel perforation, bleeding, and the need for surgical intervention. Bowel preparation was defined as a traumatic breach of intestinal integrity. Bleeding is defined as evident blood loss that is associated with polypectomy, biopsy, or rarely, after colonoscopy without intervention. Surgical intervention involves the management of perforation or severe bleeding that cannot be treated otherwise. The occurrence or need for any of these is marked with YES or NO.

\section{Statistical Analysis}

The data analysis was performed using the Statistical Package for the Social Sciences (v23.0; IBM Corp., Armonk, NY, USA). Descriptive statistics, in terms of mean, standard deviation, frequency, and percentage, were derived for numerical parameters in the study. The chi-square test was used to analyze categorical parameters and the type of colonoscopy. The normality of numerical variables was tested by using the Kolmogorov-Smirnov normality test. $\mathrm{P}$-values of $<0.05$ are considered significant.

\section{RESULTS}

The mean age of the participants was 55.76 years; 40 (28.6\%) were males and 100 (71.4\%) were females. The mean body weight was 76.79 kilograms, ASA I was noted in 45 (32.1\%) and ASA II in 95 (67.9\%) patients. The majority of colonoscopies were therapeutic in 121 (86.4\%) and diagnostic in 14 (10\%) (Table 1). Mean values of adenoma location, biopsies, and polypectomy were also analyzed. The largest number of adenomas/polyps were localized in the rectum and then in the sigmoid and ascending colon, without statistically significant difference $(p=0.11)$. Most biopsies were performed in the sigmoid colon and the second place in the ileum $(p<0.05)$. Polypectomies were mostly performed in the rectum, sigmoid colon, and ascending colon, in order, $(p<0.05)$ as shown in Table 2, with a statistically significant difference in the localization of biopsies and polypectomies. The ADR was $43.6 \%, 55 \%$ in males, and $39 \%$ in females. The overall rates of adenoma, biopsies, and polypectomy were $43.6 \%, 17.9 \%$, and $22.9 \%$, respectively. The percentage of cecal intubation was high with a $93.6 \%$ with withdrawal time of $>6 \mathrm{~min}$ in most patients $(80 \%)(p<0.05)$, and $<6$ minutes in $20 \%$ of patients $(p<0.05)$. The quality of bowel preparation according to the CHBP scale showed that our patients were relatively well prepared, 1 patient with large $(0.7 \%), 13$ patients with moderate $(21.4 \%), 71$ patients with minimal (50.7\%), and 38 patients with a little amount of fluid $(27.1 \%)(p<0.05)$. Complications, such as perforation, bleeding, and the need for surgical intervention, were not noted $(p<0.05)$ (Table 3$)$.

\section{DISCUSSION}

This prospective observational study analyzed the effects of ketamine-based sedation techniques on ADR value as a quality metric. Baseline characteristics (age, body weight, gender, ASA score, and type of colonoscopy), quality of bowel preparation according to CHBP scale, cecal intubation, withdrawal time, and complications are monitored. Our results revealed a satisfactory overall ADR value, as well as a good value when it comes to the female gender. For males, this form of sedation has not

Table 1. Demographic data, ASA score, and type of colonoscopy (diagnostic and therapeutic).

\begin{tabular}{|c|c|c|c|}
\hline \multicolumn{3}{|l|}{ Variable } & p-value \\
\hline Age mean $\pm S D$ & \multicolumn{2}{|c|}{$55.76 \pm 12.97$} & - \\
\hline $\mathrm{BW}$ mean $\pm \mathrm{SD}$ & \multicolumn{2}{|c|}{$76.79 \pm 14.14$} & - \\
\hline \multirow{2}{*}{ Sex n (\%) } & Male & $40(28.6 \%)$ & \multirow{2}{*}{$<0.05$} \\
\hline & Female & 100 (71.4\%) & \\
\hline \multirow{2}{*}{ ASA status n (\%) } & 1 & $45(32.1 \%)$ & \multirow{2}{*}{$<0.05$} \\
\hline & II & 95 (67.9\%) & \\
\hline \multirow{2}{*}{ Diagnostic n (\%) } & Yes & 14 (10.0\%) & \multirow{2}{*}{$<0.05$} \\
\hline & No & $126(90.0 \%)$ & \\
\hline \multirow{2}{*}{ Therapeutic n (\%) } & Yes & $121(86.4 \%)$ & \multirow{2}{*}{$<0.05$} \\
\hline & No & 19 (13.6\%) & \\
\hline
\end{tabular}

SD: Standard deviation, ASA status: Physical status classification system according to American Society of Anaesthesiologists, BW: Body weight 


\begin{tabular}{|c|c|c|c|}
\hline Variable & Location & Mean \pm SD & p-value \\
\hline \multirow{7}{*}{ Adenoma/polyp } & Rectum & $0.17 \pm 0.50$ & \multirow{7}{*}{0.11} \\
\hline & Descending & $0.11 \pm 0.36$ & \\
\hline & Sigmoid & $0.23 \pm 0.82$ & \\
\hline & Ascending & $0.15 \pm 0.44$ & \\
\hline & Transverse & $0.04 \pm 0.23$ & \\
\hline & Caecum & $0.09 \pm 0.34$ & \\
\hline & Ileum & $0.05 \pm 0.21$ & \\
\hline \multirow{7}{*}{ Biopsy } & Rectum & $0.13 \pm 0.70$ & \multirow{7}{*}{$<0.05$} \\
\hline & Descending & $0.06 \pm 0.52$ & \\
\hline & Sigmoid & $0.28 \pm 1.33$ & \\
\hline & Ascending & $0.01 \pm 0.11$ & \\
\hline & Transverse & $0.07 \pm 0.61$ & \\
\hline & Cecum & $0.04 \pm 0.43$ & \\
\hline & Ileum & $0.14 \pm 0.76$ & \\
\hline \multirow{7}{*}{ Polypectomy } & Rectum & $0.09 \pm 0.30$ & \multirow{7}{*}{$<0.05$} \\
\hline & Descending & $0.06 \pm 0.23$ & \\
\hline & Sigmoid & $0.09 \pm 0.37$ & \\
\hline & Ascending & $0.09 \pm 0.38$ & \\
\hline & Transverse & $0.01 \pm 0.11$ & \\
\hline & Cecum & $0.05 \pm 0.21$ & \\
\hline & Ileum & $0.01 \pm 0.08$ & \\
\hline
\end{tabular}

shown significance with the ADR, probably due to the small number of male patients in our study group. A high percentage of adenoma detection performed biopsies, and polypectomies had statistical significance, including other analyzed variables, cecal intubation, withdrawal time, and CHBP scale without notated complications. Large variations in the ADR values are observed and are directly related to the outcome of colorectal cancer ${ }^{8}$. Several studies also analyzed the relationship of the ADR with other factors ${ }^{9,10}$. The main risk factors include age, male gender, obesity, and family history. Age as a factor has the same relevance in both sexes. More than $50 \%$ of colorectal cancers are detected after the age of 70 years and only $10 \%$ before the age of 55 . However, the risk of advanced cancer in males is twice as high as in females". Male gender increases the risk to a similar extent as the positive family history of this malignant disease. Whether and how the ADR should be adjusted for the presence of other risk factors, other than gender, remains unclear ${ }^{12}$. Regarding ASA status, no studies have examined the relationship of ASA status with ADR. Studies have analyzed the relationship between ADR and other comorbidities. One study analyzed diabetes [diabetes mellitus (DM)], and obesity and revealed a significantly higher ADR in patients with DM and obesity compared with patients without such comorbidities ${ }^{13}$.

\begin{tabular}{|c|c|c|c|}
\hline \multicolumn{2}{|l|}{ Variable } & n (\%) & p-value \\
\hline \multicolumn{2}{|l|}{ ADR, no/yes } & $79 / 61$ (56.40/43.60) & \multirow{3}{*}{0.030} \\
\hline \multicolumn{2}{|l|}{ Male } & $18 / 22(12.85 / 15.71)$ & \\
\hline \multicolumn{2}{|l|}{ Female } & $61 / 39(43.57 / 27.86)$ & \\
\hline \multicolumn{2}{|l|}{ Adenoma, no/yes } & 79/61 (56.40/43.60) & $<0.05$ \\
\hline \multicolumn{2}{|l|}{ Biopsy, no/yes } & $115 / 25(82.10 / 17.90)$ & $<0.05$ \\
\hline \multicolumn{2}{|c|}{ Polypectomy, no/yes } & $108 / 32(77.10 / 22.90)$ & $<0.05$ \\
\hline \multicolumn{2}{|c|}{ Cecal intubation, no/yes } & 9/131 (6.40/93.60) & $<0.05$ \\
\hline \multirow{2}{*}{ Withdrawal time } & $>6 \min$ & $28(20.00)$ & \multirow{2}{*}{$<0.05$} \\
\hline & $<6 \min$ & $112(80.00)$ & \\
\hline \multirow{4}{*}{ CHBP scale } & Large & $1(0.70)$ & \multirow{4}{*}{$<0.05$} \\
\hline & Moderate & $30(21.40)$ & \\
\hline & Minimal & $71(50.70)$ & \\
\hline & Little fluid & $38(27.10)$ & \\
\hline \multicolumn{4}{|l|}{ Complications } \\
\hline Perforation & & 140/0 (100.00/0.00) & \multirow{3}{*}{$<0.05$} \\
\hline Bleeding & & 140/0 (100.00/0.00) & \\
\hline \multicolumn{2}{|c|}{ Surgical intervention } & 140/0 (100.00/0.00) & \\
\hline
\end{tabular}


Based on many studies, recent screening guidelines have identified obesity as a higher risk for colorectal neoplasia compared to individuals without this risk factor. Additionally, obesity has also been highlighted as an indicator of colonoscopy quality ${ }^{14}$. Some authors have studied colonoscopies performed after previous therapeutic or diagnostic colonoscopies to arrive at a true and relevant $A D R^{15,16}$. Our findings revealed that more adenomas were more commonly found in the transverse colon; however, the likelihood of one or more biopsies was significantly higher in the colon ascending and cecum. This observation is partly consistent with the research of Köksal et al. ${ }^{17}$, wherein the most common location of detected adenomas was in the transverse and sigmoid colon. Our study results revealed a statistically significant difference in the detection of adenomas, polyps with or without polypectomy, and with or without biopsy, which in itself can be used as a measure of quality ${ }^{18}$.

The distribution of adenomas or polyps according to our results is partly consistent with the study of Kim et al. ${ }^{19}$, according to which they classified colorectal carcinoma as left- and right-sided. Cecal intubation was also included in our research to find the right quality standards. A previous study revealed that the relationship between the ADR and the cecal intubation was satisfactory, and together they represent good markers of a comprehensive colonic mucosa examination ${ }^{20}$, which we included and analyzed in our study. A colonoscopy withdrawal time of at least $6 \mathrm{~min}$ is the standard for achieving the goal of polyp detection rate and ADR. Colonoscopies with a withdrawal time of $<6$ min cannot achieve the targeted ADR. According to a study by Wong et al. ${ }^{21}$, this time improves the rate of detection of intestinal changes in screening colonoscopy. The optimal clinical criteria for bowel quality preparation remain controversial. Our study used a CHBP scale according to which scoring was performed both before and after washing or use, and a separate result for the liquid was included as a secondary measure. This scale has its insufficiency, but due to its practicality and better definition, it is well accepted ${ }^{22}$. This scale, according to our results, showed a good correlation with the ADR, contrary to the Aronchick scale, which did not have $\mathrm{it}^{23}$. Complications during colonoscopy are very rare, which were confirmed with our results. They mainly refer to bleeding and perforation, and consequently, to the need for surgical intervention. The perforation rate of reported complications in large studies is generally $<0.1 \%$, including a 6 per 10,000 risk of perforation and a 26 per 10,000 risk of bleeding ${ }^{24}$. Colonoscopy-related bleeding is more frequent and is mostly associated with the previous polypectomy ${ }^{25}$.
This study has several limitations. As mentioned, it is single-center on a relatively small number of patients. Two practitioner endoscopists performed the procedure in the studied endoscopic group of patients, which was not taken into analysis. However, this only reflects the actual practice in many endoscopic units. Furthermore, we did not analyze the relationship between the ADR and polyp detection rate that could be also used as a marker of the ADR.

\section{CONCLUSIONS}

Thus, subsequent studies should analyze these in the future. This study revealed that ketamine-based sedation is a satisfactory anesthetic technique because the overall ADR is acceptable and above the previously established benchmark. However, the adoption of this practice would require a lot of further research to determine the actual relationship between the anesthesia technique and the ADR. Therefore, the degree of detection of adenomas and other precancerous lesions, with the prognosis in colorectal cancer, has an anesthetic technique. In the future, we suggest that ketamine-based sedation should be included as a reliable indicator of endoscopy quality, as well as metric quality.

\section{Ethics}

Ethics Committee Approval: This study approved by Cantonal Hospital Zenica Ethics Committee (decision no: 00-03-35-1277-9/20, date: 30.06.2020).

Informed Consent: Informed consent was taken from the participants of the study.

Peer-review: Externally and internally peerreviewed.

\section{Author Contributions}

Surgical and Medical Practices: N.R., Concept: M.K., Design: M.K., Data Collection and/or Processing: A.A., Analysis and/or Interpretation: N.R., Literature Search: N.B., Writing: A.S.A.

Conflict of Interest: The authors have no conflict of interest to declare.

Financial Disclosure: The authors declared that this study has received no financial support.

\section{REFERENCES}

1. Rawla P, Sunkara T, Barsouk A. Epidemiology of colorectal cancer: incidence, mortality, survival, and risk factors. Prz Gastroenterol. 2019;14:89-103.

2. Mattiuzzi C, Sanchis-Gomar F, Lippi G. Concise update on colorectal cancer epidemiology. Ann Transl Med. 2019;7:609. 
3. Kahi CJ, Imperiale TF, Juliar BE, Rex DK. Effect of screening colonoscopy on colorectal cancer incidence and mortality. Clin Gastroenerol Hepatol. 2009;7:770-5.

4. Anderson JC, Butterly LF. Colonoscopy: Quality Indicators. Clini Transl Gastroenterol. 2015;6:e77.

5. Corley DA, Jensen CD, Marks AR, et al. Adenoma detection rate and risk of colorectal cancer and death. N Engl J Med. 2014;370:1298-306.

6. Pullens HJ, Siersema PD. Quality indicators for colonoscopy: Current insights and caveats. World J Gastrointest Endosc. 2014;612:571-83.

7. Diamond SJ, Enestvedt BK, Jiang Z, et al. Adenoma detection rate increases with each decade of life after 50 years of age. Gastrointest Endosc. 2011;74:135-40.

8. Cross AJ, Robbins EC, Saunders BP, Duffy SW, Wooldrage K. Higher Adenoma Detection Rates at Screening Associated With Lower Long-Term Colorectal Cancer Incidence and Mortality. Clin Gastroenterol and Hepatol. 2022;20:e148-67.

9. Leon Moreno JF. ADR evaluation of screening colonoscopies during 2016 - 2017 in a private health clinic in Peru. Endosc Int Open. 2018;06:E1304-9.

10. Wang $\mathrm{H}$, Wang $\mathrm{P}$, Liu $\mathrm{X}$, et al. Factors predicting the colorectal adenoma detection rate in colonoscopic screening of a Chinese population: A prospective study. Medicine (Baltimore). 2019;98:15:el5103.

11. Coe SG, Wallace MB. Assessment of adenoma detection rate benchmarks in women versus men. Gastrointest Endosc. 2013;77:631-5.

12. Anderson JC, Weiss JE, Robinson CM, Butterly L. Adenoma Detection Rates for Screening Colonoscopies in Smokers and Obese Adults: Data from the New Hampshire Colonoscopy Registry. J Clin Gastroenterol. 2017;51:e95-100.

13. Soltani G, Poursheikhani A, Yassi M, Hayatbakhsh A, Kerachian $M$, Kerachian MA. Obesity, diabetes and the risk of colorectal adenoma and cancer. BMC Endocr Disord. 2019;19:113.

14. Anderson JC, Messina CR, Dakhllalah F, et al. Body mass index: a marker for significant colorectal neoplasia in a screening population. J Clin Gastroenterol. 2007;41:285-90.
15. Bae T, Ha Y, Kim C, et al. Distribution of the colonoscopic adenoma detection rate according to age: is recommending colonoscopy screening for koreans over the age of 50 safe?. Ann Coloproctol. 2015:31:46-51.

16. Raju CS, Vadyala V, Slack R, et al. Adenoma detection in patients undergoing a comprehensive colonoscopy screening. Cancer Med. 2013;2:391-402.

17. Köksal AŞ, Kalkan IH, Torun S, et al. A simple method to improve adenoma detection rate during colonoscopy: Altering patient position. Can J Gastroenterol. 2013;27:509-12

18. Williams JE, Holub JL, Faigel DO. Polypectomy rate is a valid quality measure for colonoscopy: results from a national endoscopy database. Gastrointest Endosc. 2012;75:576-82.

19. Kim SE, Paik HY, Yoon H, Lee JE, Kim N, Sung MK. Sex- and gender-specific disparities in colorectal cancer risk. World J Gastroenterol. 2015;21:5167-75.

20. Ruiz-Rebollo ML, Alcaide-Suárez N, Burgueño-Gómez B, et al. Adenoma detection rate and cecal intubation rate: Quality indicators for colonoscopy. Gastroenterol Hepatol. 2019;42:253-5.

21. Wong WJ, Arafat Y, Wang S, Hawes S, Hung K. Colonoscopy withdrawal time and polyp/adenoma detection rate: a singlesite retrospective study in regional Queensland. ANZ J Surg. 2020;90:314-6.

22. Gerard DP, Foster DB, Raiser MW, Holden JL, Karrison TC Validation of a new bowel preparation scale for measuring colon cleansing for colonoscopy: the chicago bowel preparation scale. Clin Transl Gastroenterol. 2013;4:e43.

23. Park JH, Kim SJ, Hyun JH, et al. Correlation Between Bowel Preparation and the Adenoma Detection Rate in Screening Colonoscopy. Ann Coloproctol. 2017;33:93-8.

24. Tomaszewski M, Sanders D, Enns R, et al. Risks associated with colonoscopy in a population-based colon screening program: an observational cohort study. CMAJ Open. 2021;9:E940-7.

25. Turan AS, Moons LMG, Schreuder RM, et al. Clip placement to prevent delayed bleeding after colonic endoscopic mucosal resection (CLIPPER): study protocol for a randomized controlled trial. Trials. 2021;22:63. 